\title{
Assessment of Foreign Trade Liberalization Impacts on Trade Flows by Gravity Method: Azerbaijan Case
}

\author{
Mayis Gulaliyev ${ }^{1}$, Bayramov Shahin ${ }^{2}$ and Suriya Abasova ${ }^{3}$ \\ ${ }^{1}$ Associate Professor, the Institute of Economics of Azerbaijan National Academy of Sciences, Baku, \\ Azerbaijan. \\ ${ }^{2}$ Associate Professor, Azerbaijan State University of Economics (UNEC), Azerbaijan \\ ${ }^{3} \mathrm{Ph} . \mathrm{D}$ Candidate, the Institute of Economics of Azerbaijan National Academy of Sciences, Baku, Azerbaijan
}

\begin{abstract}
Research objective of the paper is to investigate influence of some factors, especially liberalization of foreign trade and distance between countries to the volume of export and import. For trade flows analysis there were applied gravity method of Tinbergen and comparative analysis. As liberalization level of foreign trade there was developed foreign trade sub-index. The authors concluded that the trade flows volume between the countries strongly depends on the distance and on the economic development level, as well as on foreign trade liberalization level. The export flows volume between Azerbaijan and its main partners proves this hypothesis. But the import flows volume has a weak relationship with foreign trade liberalization level.
\end{abstract}

Keywords: trade flows, import, export, liberalization, gravity method, foreign trade sub-index

\section{Introduction}

Trade relations between countries are influenced by various factors, including tariffs, cost and quality of goods, distances between countries, relations between countries and others. Undoubtedly, if there were no tariff restrictions, the volume of foreign trade between countries would also be different. Or if quality and value would not affect trade relations, then they would not make any efforts to improve the quality of goods. On the other hand, trade relations are seriously affected by the distance between countries, transport corridors and others. Under the same other conditions, every country seeks to create market relations most of all with neighboring countries. However, the variety of relations between countries, situations within countries, levels of production, differences between production factors, etc. creates comparative and competitive advantages between countries. In such circumstances, the choice of the most important of these factors for a particular country, including Azerbaijan, is important in the development of foreign trade and the management of foreign trade.

\section{Literature review}

The study of foreign trade flows and the factors on which their volume depends were considered by various economists as an object of study Clarete et al. [1] used the gravity model of bilateral trade to assessment trade flows in the Asia-Pacific region. Ram and Prasad [2] used gravity model to investigate world trade potential of Fiji. Shakibaee et al. [3] measured the trade potential of Iran and Turkey countries by by gravity model. Rahman and Ara [4] used gravity approach to estimate foreign trade potential for Bangladesh. Matias [5] used gravity model to calculate trade efficiency and potential of China. Gebrehiwot [6] utilised a dynamic gravity approach to analyze the trade pattern of Ethiopia. Ravishankarand and Stack [7] applied of the gravity model to determine trade efficiency. Nishitateno [8] used the gravity model to determine the network effects on auto parts exports from six major automobile producing countries. Akhvlediani and Śledziewska [9] analyzed the impacts 
of Common Commercial Policy (CCP) on the export performances with the use of the augmented gravity model. These and other investigations are very interesting and important to understand characteristics of foreign trade flows. But there is not any investigation that taking into account the liberalization factors in gravity model. We tried to include the liberalization factor to the gravity model.

\section{Methodology}

In our investigation we will use the gravity model [10] to determine the trade flows between two countries, and foreign trade freedom that will be measured as a sub-index of foreign trade [11].

The Tinbergen model is based on a fairly simple logic. The volume of exports from any country is affected by 1) the volume of GDP of this country; 2) the volume of GDP of the country importing these goods; 3) the distance between these countries. In the first approach, the Tinbergen model determines the dependence of export volume only on these three indicators. With other approaches, other indicators are introduced, for example, the presence of conditions for intercountry benefits, conditions for the neighborhood of countries, etc., and the model is a bit more complicated. However, indicators introduced by other approaches have a lower degree of significance than primary indicators.

It is important to note some features of the Tinbergen model. So, 1) a separate demand and supply function for export is not calculated; 2) export is considered as a statistical process, and not as dynamic and does not take into account the time factor. Of the three indicators adopted as the main factors affecting the volume of trade, the third, that is, the intercountry distance, negatively affects the volume of trade. Since increasing the distance also increases transportation costs. Thus, the volume of exports between the two Tinbergen countries is expressed in the following formula.

$$
\begin{gathered}
Y_{i j}=a_{0} * X_{i}^{a 1} * X_{j}^{a 2} * D_{i j}^{a 3} \\
\text { or } \\
\log Y_{i j}=\log a_{0}+a 1 * \log X_{i}+a 2 * \log X_{j}+a 3 * \log D_{i j}
\end{gathered}
$$

where, $Y_{i j}$ - export volume from country $i$ to country $j, X_{i}$ - volume of GDP of the country $i, X_{j}$ - volume of GDP of the country $\mathrm{j}, \mathrm{D}_{\mathrm{ij}}$ - distance between countries $\mathrm{i}$ and $\mathrm{j}$.

As shown in these models proposed by Tinbergen, the volume of exports between the two countries may not depend linearly on these three factors. The indices a1, a2, a3 express the elasticity of export volume for these variables. For example, if other indicators remain unchanged, if the volume of GDP of the exporting country changes by $1 \%$, then the volume of exports changes by al percent.

In reality trade flows volume between countries depend on foreign trade regimes as well. That is why it is necessary to add to the (1) and (2) equations a factor that determines liberalization level of foreign trade liberalization. We will use an indicator called foreign trade sub-index [11]. Foreign trade subindex as composite index is made up of three sub-subindices, first of them is foreign trade procedures, second- freedom of foreign trade index, that is calculated by the Fraser Institute. The third sub-subindex of foreign trade subindex is the participation in international trade or economic value of imports index that is calculated by World Economic Forum. The fourth sub-subindex of foreign trade subindex is the freedom of trade index, which is calculated using the methodology developed by The Heritage Foundation.

By adding the foreign trade sub-index factor to the equations (1) and (2) we have changed these equations as follows:

$$
\begin{gathered}
Y_{i j}=a_{0} * X_{i}^{a 1} * X_{j}^{a 2} * D_{i j}^{a 3} * F T_{i}^{a 4} * F T_{j}^{a 5} \\
\text { or } \\
\log Y_{i j}=\log a_{0}+\alpha 1 * \log X_{i}+a 2 * \log X_{j}+a 3 * \log D_{i j}+a 4 * \log F T_{i}+a 5 * \log F T_{j}
\end{gathered}
$$

Where $\boldsymbol{F} \boldsymbol{T}_{\boldsymbol{i}}$ and $\boldsymbol{F} \boldsymbol{T}_{j}$ are foreign trade indices in the i and $\mathrm{j}$ countries respectively. 


\section{Results}

Table I: Assessment of relations between major trading partners and Azerbaijan, as a country of importer or exporter (2015)

\begin{tabular}{|c|c|c|c|c|c|c|}
\hline & country & $\begin{array}{l}Y_{\mathrm{i}}-\mathrm{GDP} \\
(\$)\end{array}$ & $\begin{array}{l}D_{i j} \text {-distance } \\
(\mathrm{km})\end{array}$ & $\begin{array}{l}F_{i}-\text { foreign trade sub- } \\
\text { index of countries } i\end{array}$ & $\begin{array}{l}\overline{\mathrm{I}}_{\mathrm{i}}-\text { export volume from } \\
\text { the country } i \text { (тыс. } \$ \text { ) }\end{array}$ & $\begin{array}{l}E_{\mathrm{i}}-\text { import volume to the } \\
\text { country } i \text { (thousend \$) }\end{array}$ \\
\hline 1 & USA & $1,7947 \mathrm{E}+13$ & 9372,52 & 0,21 & 337704,4 & 847389,4 \\
\hline 2 & Germany & $3,35577 \mathrm{E}+12$ & 3060,76 & 0,23 & 1223962,0 & 690082,4 \\
\hline 3 & Australia & $1,33954 \mathrm{E}+12$ & 13172,96 & 0,20 & 613,7 & 9105,3 \\
\hline 4 & Austria & $3,74056 \mathrm{E}+11$ & 2780,23 & 0,23 & 407348,4 & 118444,8 \\
\hline 5 & UAE & $3,70293 \mathrm{E}+11$ & 1765,47 & 0,23 & 5698,8 & 66669,7 \\
\hline 6 & Bulgaria & 48952959080 & 2216,73 & 0,24 & 497,9 & 12721,6 \\
\hline 7 & Bosnia & 15995392118 & 2608,76 & 0,23 & 0,5 & 471,5 \\
\hline 8 & Great Britain & $2,84876 \mathrm{E}+12$ & 3974,59 & 0,20 & 10666,1 & 553325,5 \\
\hline 9 & Brazil & $1,77472 \mathrm{E}+12$ & 11892,14 & 0,36 & 192,3 & 119710,0 \\
\hline 10 & S. Africa & $3,12798 \mathrm{E}+11$ & 7690,44 & 0,28 & 4,7 & 3031,8 \\
\hline 11 & Czech & $1,81811 \mathrm{E}+11$ & 2944,51 & 0,23 & 549516,3 & 58376,6 \\
\hline 12 & China & $1,08664 \mathrm{E}+13$ & 5519,20 & 0,36 & 53194,8 & 511904,6 \\
\hline 13 & Denmark & $2,95164 \mathrm{E}+11$ & 3198,11 & 0,22 & 72,0 & 16638,0 \\
\hline 14 & Estonia & 22691482755 & 2745,74 & 0,21 & 253,4 & 5697,9 \\
\hline 15 & Finland & $2,2981 \mathrm{E}+11$ & 2790,26 & 0,21 & 189,2 & 34545,2 \\
\hline 16 & France & $2,42168 \mathrm{E}+12$ & 3813,35 & 0,24 & 864155,8 & 212250,6 \\
\hline 17 & Georgia & 13965385802 & 447,23 & 0,14 & 365954,6 & 67992,6 \\
\hline 18 & India & $2,07354 \mathrm{E}+12$ & 2800,24 & 0,47 & 270235,1 & 34797,3 \\
\hline 19 & Indonesia & $8,61934 \mathrm{E}+11$ & 7789,76 & 0,28 & 477818,9 & 19914,6 \\
\hline 20 & Iran & $3,937 \mathrm{E}+11$ & 542,08 & 0,70 & 33330,5 & 90455,4 \\
\hline 21 & Ireland & $2,3802 \mathrm{E}+11$ & 4379,20 & 0,20 & 52235,8 & 11888,7 \\
\hline 22 & Spain & $1,19906 \mathrm{E}+12$ & 4467,73 & 0,23 & 316057,4 & 61561,1 \\
\hline 23 & Israel & $2,96075 \mathrm{E}+11$ & 1637,25 & 0,20 & 801533,4 & 24871,7 \\
\hline 24 & Sweden & $4,92618 \mathrm{E}+11$ & 3052,11 & 0,23 & 134,4 & 80084,0 \\
\hline 25 & Swiss & $6,64738 \mathrm{E}+11$ & 3447,73 & 0,26 & 96792,3 & 99204,7 \\
\hline 26 & Italy & $1,81476 \mathrm{E}+12$ & 3111,79 & 0,24 & 2254330,5 & 587767,5 \\
\hline 27 & Canada & $1,55054 \mathrm{E}+12$ & 9052,61 & 0,19 & 223722,6 & 16632,1 \\
\hline 28 & Cyprus & 19319729400 & 1559,24 & 0,23 & 8,6 & 9754,2 \\
\hline 29 & Latvia & 27035266718 & 2611,45 & 0,22 & 800,5 & 8342,4 \\
\hline 30 & Lithuania & 41243983587 & 2414,43 & 0,24 & 512,9 & 26941,9 \\
\hline 31 & Luxemburg & 57793612066 & 3535,98 & 0,22 & 179,8 & 8772,0 \\
\hline 32 & Hungary & $1,20687 \mathrm{E}+11$ & 2573,84 & 0,23 & 240,9 & 27719,3 \\
\hline 33 & Malaysia & $2,96218 \mathrm{E}+11$ & 6638,88 & 0,27 & 11159,9 & 77840,7 \\
\hline 34 & Malta & $1,10 \mathrm{E}+10$ & 3124,24 & 0,22 & 141929,3 & 99,0 \\
\hline 35 & Mexico & $1,14433 \mathrm{E}+12$ & 12642,27 & 0,25 & 42,6 & 22217,7 \\
\hline 36 & Egypt & $3,30779 \mathrm{E}+11$ & 2042,94 & 0,43 & 109,5 & 3595,7 \\
\hline 37 & Moldova & 6551161404 & 1835,53 & 0,28 & 448,3 & 3559,5 \\
\hline 38 & Montenegro & 3992640233 & 2551,03 & 0,20 & 3,8 & 0,5 \\
\hline 39 & Nederland & $7,52547 \mathrm{E}+11$ & 3631,00 & 0,21 & 101792,1 & 102826,5 \\
\hline 40 & Norway & $3,88315 \mathrm{E}+11$ & 3452,14 & 0,23 & 1152,0 & 144275,0 \\
\hline 41 & Poland & $4,74783 \mathrm{E}+11$ & 2554,03 & 0,24 & 6509,0 & 90732,7 \\
\hline 42 & Portugal & $1,98931 \mathrm{E}+11$ & 4970,42 & 0,23 & 368874,4 & 26204,5 \\
\hline 43 & Kazakhstan & $1,84361 \mathrm{E}+11$ & 2047,74 & 0,40 & 17957,8 & 98925,6 \\
\hline 44 & Kirgizia & 6571853849 & 2065,71 & 0,19 & 6561,0 & 1604,2 \\
\hline 45 & Romania & $1,77954 \mathrm{E}+11$ & 1995,91 & 0,31 & 83934,5 & 64709,3 \\
\hline 46 & Russia & $1,32602 \mathrm{E}+12$ & 1929,55 & 0,23 & 416770,8 & 1437901,3 \\
\hline 47 & Serbia & 36513027128 & 2445,33 & 0,42 & 41,0 & 3954,5 \\
\hline 48 & Singapore & $2,92739 \mathrm{E}+11$ & 6946,75 & 0,33 & 281,7 & 103489,5 \\
\hline 49 & Slovakia & 86581789952 & 2725,36 & 0,34 & 55,6 & 21586,1 \\
\hline 50 & Slovenia & 42746980843 & 2910,66 & 0,07 & 9429,9 & 14556,0 \\
\hline 51 & Thailand & $3,95282 \mathrm{E}+11$ & 5727,01 & 0,23 & 259115,7 & 23874,1 \\
\hline 52 & Tunisia & 43015089723 & 3618,97 & 0,24 & 291730,1 & 474,1 \\
\hline 53 & Turkey & $7,18221 \mathrm{E}+11$ & 1445,41 & 0,37 & 304298,4 & 1171385,4 \\
\hline 54 & Ukraine & 90615023324 & 1870,30 & 0,23 & 23476,5 & 309651,9 \\
\hline 55 & Croatia & 48732003674 & 2858,61 & 0,38 & 199208,6 & 1369,9 \\
\hline 56 & Japan & $4,12326 \mathrm{E}+12$ & 7532,08 & 0,25 & 871,3 & 558097,7 \\
\hline 57 & Greece & $1,95212 \mathrm{E}+11$ & 2262,84 & 0,31 & 145748,3 & 16175,5 \\
\hline
\end{tabular}


Note: calculated by authors based on [12], [13] and [14].

Table 1 shows the volume of trade relations with the main trading partners in Azerbaijan, as the country of importer or exporter, the distance between Azerbaijan and major trading cities, the volume of GDP, as well as the level of foreign trade independence in these countries (foreign trade sub-index).

Based on the Tinbergen model, the model of the volume of exports from Azerbaijan to country i can be described as follows:

$$
\log \widehat{Y}=-7,42551+1,616834 * \log (X)-2,69413 * \log (D)-3,53877 * \log (F T)
$$

where, $Y_{i}-$ volume of export from Azerbaijan to country i, X-GDP volume of the country $i, D-$ the distance between Azerbaijan and the major trading city of country i, $F$ - foreign trade sub-index of Azerbaijan's export partner. In the regression equation expressing the dependence of export volume in accordance with the variables shown in table 1 from other variables, the coefficient of the regression set is

$$
R=0,623049, \log \alpha_{0}=-7,42551, a 1=1,616834, a 2=-2,69413, a 3=-3,53877 .
$$

Analysis of regression relations suggests that Azerbaijan has additional opportunities to increase export relations with the UAE, Bulgaria, Bosnia, China and other countries. And with some countries, for example, Indonesia, Ireland, etc., the volume of exports is greater than in the model. Regression relations also express the extent to which foreign trade restrictions affect the volume of exports.

That is, if you do not take into account foreign trade restrictions, then the index of regression of export volume in the above model of dependence will be $\mathrm{R}=0.58130$. Thus, the sub-index of foreign trade should be included in the Tinbergen model as an important factor in foreign trade flow.

Chart 1 shows the dependence of Azerbaijan's exports on the sub-index of foreign trade of partner countries. The graph shows that the main export partners of Azerbaijan are countries with sub-indices of foreign trade below 0.28 . That is, in the foreign trade sphere, Azerbaijan mainly cooperates with liberal countries.

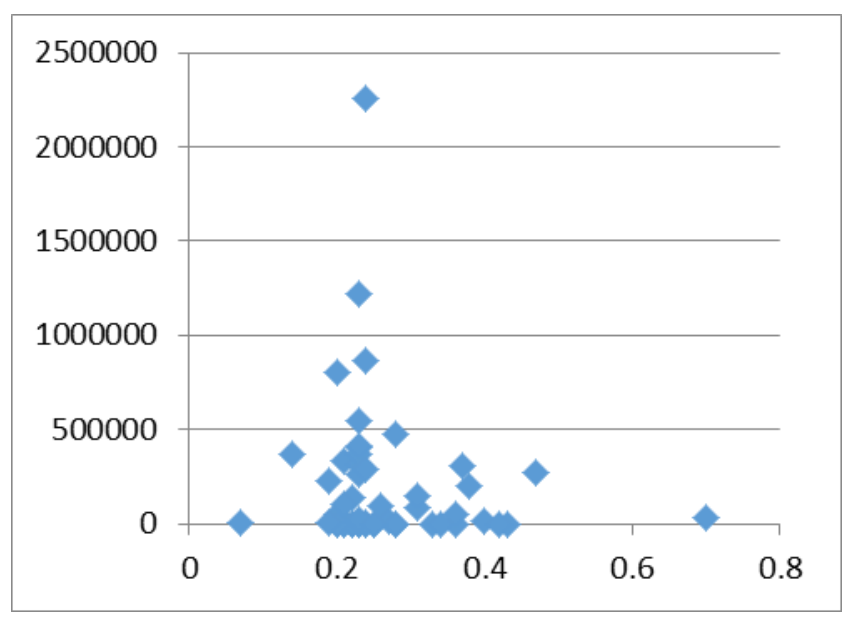

Fig.1. The relationship between Azerbaijan's export volume and the foreign trade sub-index of partner countries 


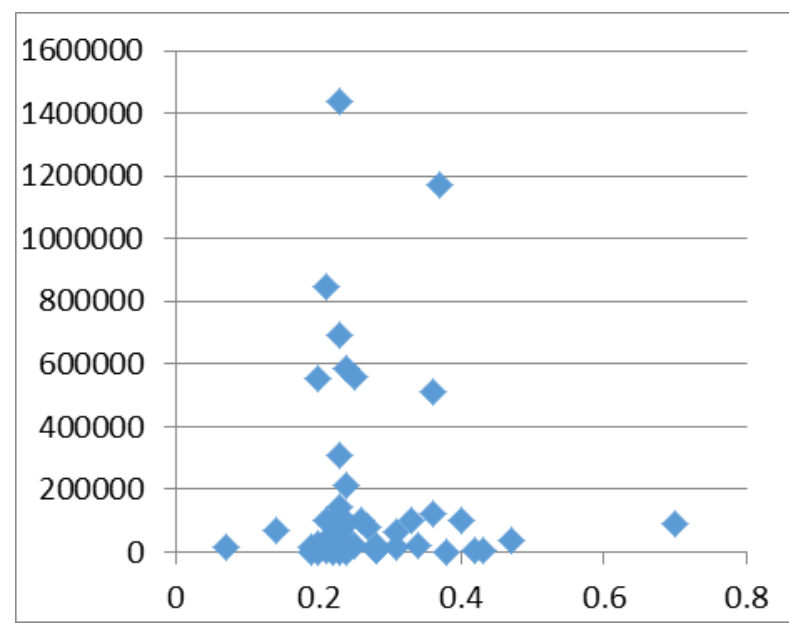

Fig.2. The relationship between the volume of imports of Azerbaijan and the foreign trade sub-index of partner countries

It is also possible to analyze the volume of imports from other countries. According to the Tinbergen model, the model of the volume of imports from country i can be obtained as follows:

$$
\log \widehat{Y}=-5,23737+1,27326 * \log (X)-1,62834 * \log (D)-1,33974 * \log (F T)
$$

Где, $Y_{i}$ - import volume from country $i$ to Azerbaijan, $X_{i}$ - GDP volume of the country $i, D_{i}-$ distance between Azerbaijan and a major trading city of the country i, $F_{i}$ - foreign trade sub-index of Azerbaijan's import partner. In the regression equation expressing the dependence of the volume of imports in accordance with the variables shown in table 1 from other variables, the coefficient of the regression set is

$R=0,815612 ; \log \alpha_{0}=-5,23737 ; a 1=1,27326 ; a 2=-1,62834 ; a 3=-1,33974$.

Figure 2 shows the dependence of Azerbaijan's import volume on the sub-index of foreign trade of partner countries. The graph shows that the main partners of Azerbaijan in the field of import are countries with sub-indices of foreign trade below 0.37. However, in this case, most of the goods imported into Azerbaijan belong to liberal countries.

An analysis of the regression relationship between the volume of imports of Azerbaijan from other countries allows us to say that for Azerbaijan, the above three factors can be taken as the main factors in the volume of imports, since the dependence of the volume of imports on these three factors is quite strong. In this case, along with factors of GDP volume and distances between importing countries, the inclusion of foreign trade conditions of importing countries in this model does not justify itself.

Since, if the foreign trade sub-index factor is not included, the regression coefficient will be equal to $\mathrm{R}=0.803759$ and will not significantly differ from the case when it is included. This is due to the fact that import from other countries to Azerbaijan is considered an export activity for these countries, and each country in its export trade tries to support independent activity as much as possible.

The minimum dependence on the foreign trade sub-index is due to the fact that in almost all these countries export is supported and there are no restrictive measures in export. Therefore, the volume of imports to Azerbaijan does not depend on the foreign trade sub-index of the importing countries, but rather on the foreign trade sub-index of Azerbaijan itself. The same conditions apply to other countries. In other words, in almost all of these countries, it is not the export but the import that undergoes more government intervention. This can be seen from the calculations for export. As we mentioned above, Azerbaijan's export volume substantially depends both on the volume of GDP and distance, and on the foreign trade sub-index. On the other hand, the volume of imported goods to Azerbaijan 
practically does not depend on the level of conversion of purchasing power parity in other cities. For this indicator, multiple $\mathrm{R}=0.183877$. Thus, the correlation coefficient of the overall dependence on the foreign trade sub-index and the PPP conversion rate indicator is $R=0.30175$. Therefore, the inclusion of these indicators in the Tinbergen model is of little importance for the analysis of the volume of imports.

\section{Conclusion}

Thus, 1) The countries with the foreign trade sub-index less than 0.28 are the main partners in the export sector of Azerbaijan. That is, Azerbaijan in the foreign trade sphere mainly cooperates with liberal countries; 2) The main partners in the field of import of Azerbaijan are countries with a foreign trade sub-index of less than 0.37. However, in this case, most of the goods exported from Azerbaijan fall to the share of more liberal countries.

\section{References}

[1] Clarete, R., Edmonda, C., and Wallack, J.S. (2002). "Asian Regionalism and its Effects on Trade in the 1980s and 1990s”, Economics and Research Department Working Paper 30. Manila: Asian Development Bank.

https://doi.org/10.1016/S1049-0078(02)00242-7

[2] Ram, Y. and Prasad, B.C. (2007). Assessing Fiji's Global Trade Potential Using the Gravity Model Approach", USPSE Working Paper, No. 2007-05.

[3] Shakibaee, A., Kobra Bata, F., and Hyderabadi, S. (2011). “Analysis of Integration between Turkey and Iran”,Journal of Economy and Regional Development, 1(1): 74-95.

[4] Rahman, M.M. and Ara, L.A. (2010). Bangladesh Trade Potential: a Dynamic Gravity Approach, Journal of International Trade Law and Policy, 9 (2): 130-147.

https://doi.org/10.1108/14770021011054296

[5] Matias Assefa (2010). An Empirical Study of China's Trade Potential with Africa \|, MSc Thesis, Addis Ababa University.

[6] Gebreyesus Gebrehiwot and Bahre Gebru (2015). Ethiopia's foreign trade potential: inferences from a dynamic gravity approach. Int. J. Economics and Business Research, Vol. 9, No. 4, 2015, ps. 355-374

https://doi.org/10.1504/IJEBR.2015.069667

[7] Ravishankar, Geetha and Stack, Marie (2014). The Gravity Model and Trade Efficiency: A Stochastic Frontier Analysis of Eastern European Countries' Potential Trade (May 2014). The World Economy, Vol. 37, Issue 5, pp. 690704, 2014. Available at SSRN: https://ssrn.com/abstract=2434344 or http://dx.doi.org/10.1111/twec.12144

[8] Nishitateno, S. (2014). Network Effects on Trade in Intermediate Goods: Evidence from the Automobile Industry. Departmental Working Papers. The Australian National University, Arndt-Corden Department of Economics.

https://doi.org/10.1111/jere.12049

[9] Akhvlediani, T. \& Śledziewska, K. (2016). The impacts of common commercial policy on export performances of Visegrad countries. Prague Economic Papers, 26(1), 3-18.

https://doi.org/10.18267/j.pep.593

[10] Tinbergen, J. (1962). Shaping the World Economy; Suggestions for an International Economic Policy. Books (Jan Tinbergen). Twentieth Century Fund, New York. Retrieved from http://hdl.handle.net/1765/16826

[11] Gulaliyev M., Abasova S., Huseynova Sh., Azizova R., Yadigarov T. (2017). Assessment of impacts of the state intervention in foreign trade on economic growth. Espacios, vol.38, (№47) p. 33-49.

[12] World Bank (2015). https://data.worldbank.org/indicator/NY.GDP.MKTP.CD

[13] Google Maps Api (2019). http://www.distancefromto.net/ 
[14] SSCRA (2019). Official dates of State Statistical Committee of Republic of Azerbaijan. http://www.stat.gov.az/source/trade/ 